\title{
PALAEOGEOGRAPHIC EVOLUTION OF THE KERINTHOS COASTAL AREA (NE EVIA ISLAND) DURING THE LATE HOLOCENE H. MAROUKIAN ${ }^{1}$, N. PALYVOS ${ }^{1}$, K. PAVLOPOULOS ${ }^{2}$ AND E. NICOLOPOULOS ${ }^{3}$
}

\begin{abstract}
Preliminary results of a detailed study on the palaeogeographic evolution of the Kerinthos coastal archaeological area (N. Evia island) are presented. The coastal setting of Kerinthos has been subjected to important changes during the Late Holocelie, under the influence of eustatic sea-level rise, progradation of the Voudhoros river alluvial plain, and tectonic uplift. Subsurface stratigraphic data indicate that Peleki, a naturally sheltered coastal embayment that has been partially infilled by Voudhoros alluvia since at least the Classical period, had been previously a shallow, low-energy brackish water coastal environment - since at least 5000 B.P. Coastal tectonic uplift of the order of $3 \mathrm{~m}$ during the last 5 millennia is inferred from ${ }^{14} \mathrm{C}$ dated marsh deposits $(0.6 \mathrm{~mm} /$ yr minimum mean uplift rate).
\end{abstract}

KEY WORDS: Coastal geomorphology, geoarchaeology, coastal stratigraphy, coastal tectonic uplift, Holocene, Kerinthos, Voudhoros, Evia, Aegean, Greece.

\section{INTRODUCTION}

The Kerinthos archaeological area is located on the Aegean coast of north Evia (Fig. 1a/b). Little is known about the main ancient settlement and the occupation in the surrounding area. Kerinthos first appears in literature in the "catalogue of ships" in Homer's Iliad (B 538), as one of the cities that contributed ships to the Trojan

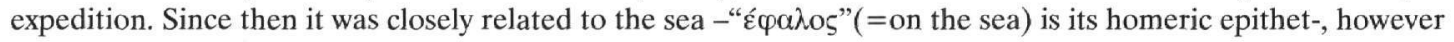
it is only briefly mentioned in later ancient texts (Sapouna-Sakellaraki, 1996). From archaeological surveys it is known that the area could have been occupied since the Neolithic period and uninterruptedly up to the Hellenistic and Roman periods (Sackett et al. 1966, Hope-Simpson \& Dickinson, 1979, Sapouna-Sakellaraki, 1996). Today Archaic (or Classical) fortification ruins and much earlier defence structures - "Cyclopean" walls- point to the location of the ancient acropolis, on top of limestone coastal cliffs (Kastri) at the area of Peleki (Fig. 1b, 2). To the W and WNW, extends the alluvial plain of the Voudhoros river, which debouches just west of the ancient acropolis.

A detailed geomorphological field survey of the broader coastal was carried out, and three shallow $(4 \mathrm{~m})$ boreholes were drilled in the Peleki embayment -a site well suited to have been the ancient port of Kerinthos- in order to study the sedimentation sequence under the Voudhoros alluvium cover, and detect palaeo-environmental changes during the late Holocene.

\section{GEOMORPHOLOGICAL EVOLUTION OF THE BROADER COASTAL AREA}

A most important agent of coastal change in the broader Kerinthos area during the Late Holocene, is the Voudhoros river. Voudhoros is the product of the confluence of rivers Nileas and Kireas, that constitute the largest drainage network in Evia island, with a watershed of $360,5 \mathrm{~km}^{2}$ (Fytrolakis et al., 1988, Leontaris \& Gournellos, 1991), extending on a variety of alpine and post-alpine formations : carbonates of the Sub-Pelagonian unit, ophiolites and melange, and Neogene fluvio-lacustrine deposits of the Limni-Histiaia basin (Katsikatsos et al., 1980, 1981). The large watershed area and dominance of easily erodible ophiolites, melange, and Neogene deposits, result into a high sediment flux in the coastal area.

Around 7000-5500 yrs BP, when the rate of the global sea-level rise started to decelerate, most of the area covered today by the coastal plain alluvium must have been a marine bay, as Fytrolakis et al. (1988) have suggested, reporting sands with marine bivalves and gastropods, presently at $1.3 \mathrm{~m}$ below m.s.l. in a borehole $900 \mathrm{~m}$ away from the coastline. Since the deceleration of the Holocene transgression, progradation of the Voudhoros

1. University of Athens, Faculty of Geology, Panepistimiopolis, 15784, Athens.

2. Harokopio University, Faculty of Geography, 70 El. Venizelou Str., 17671, Athens.

3. $11^{\text {th }}$ Ephorate of Prehistoric and Classical Antiquities, Archaeological Múseum of Chalkis, 13 El. Venizelou Str., 34100 , Chalkis. 


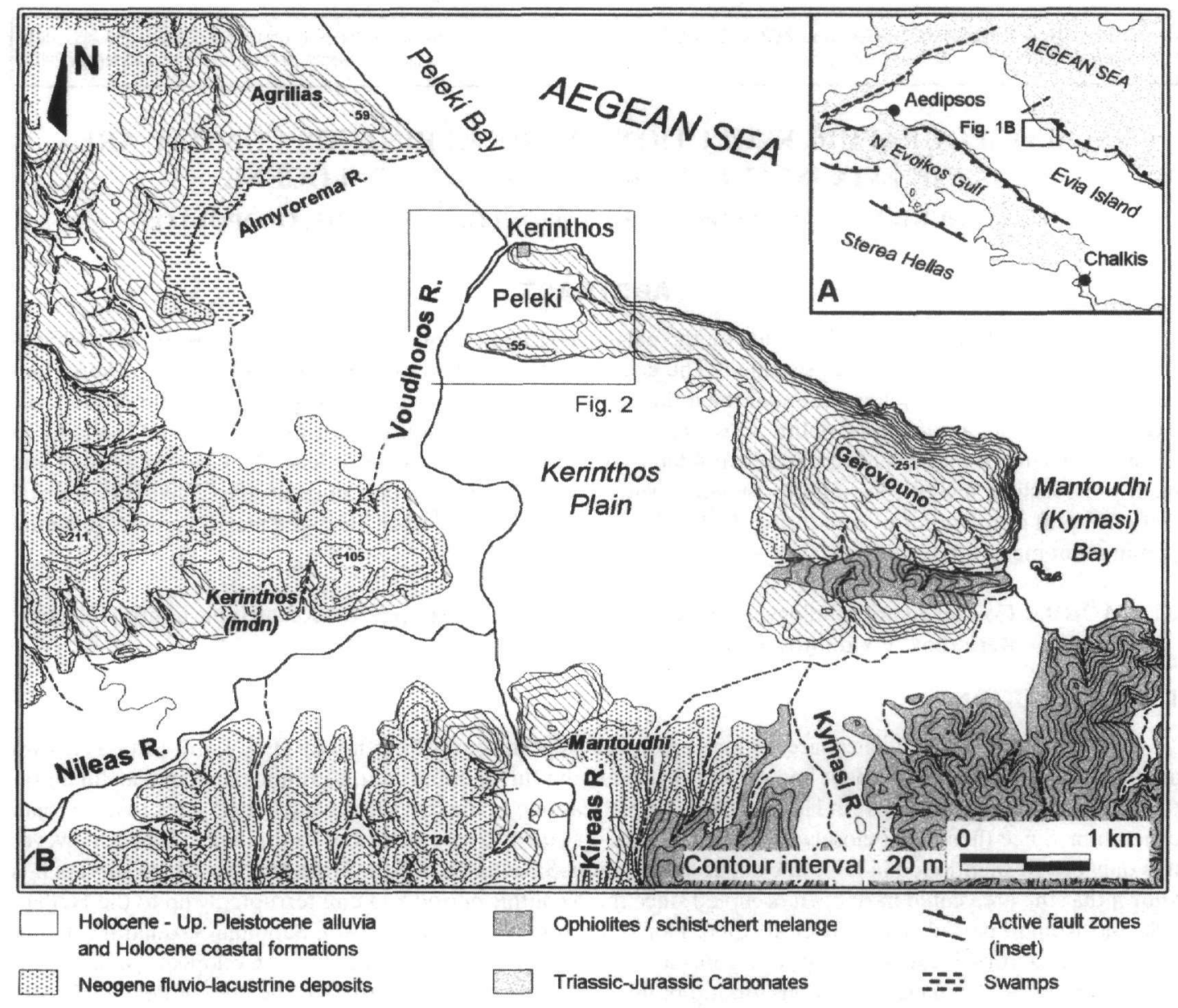

Fig. 1. (A) Location map and active fault zones. (B)Topography and lithology of the Voudhoros plain surrounding area (Katsikatsos et al., 1980, 1981).

alluvial plain was allowed, resulting in the gradual infill of the bay (the NW was only partially filled).

Apart from the interplay between eustatic sea-level rise and progradation of the Voudhoros alluvial plain, another important factor affecting the coastal evolution is tectonic uplift realised by an active offshore faultzone, paralleling the Aegean seaboard of Evia (Fig. 1a - e.g. Roberts \& Jackson, 1991). Recent coastal uplift was observed at Kymasi (Fig. 1b), where abrasion platforms around the base of ophiolite sea-stacks and at the SE end of the bay were found uplifted by about $35 \mathrm{~cm}$. Beachrocks inside the bay were found elevated by about 30 $\mathrm{cm}$ a.m.s.l. and at a small cove at the NW end of Kymasi, two wave-cut notches were observed in limestone (20 and $60 \mathrm{~cm}$ a.m.s.l. respectively). At the Kerinthos site (exactly at the mouth of Voudhoros), remains of an uplifted abrasion platform were found at about $30 \mathrm{~cm}$ a.m.s.l., together with an ill-preserved notch. Stiros et al. (1992) carbon-dated Lithofaga shells from the Kymasi notch (510-380 BC), that, according to the same authors, corresponds to an uplifted shoreline that can be observed almost continuously for about $70 \mathrm{~km}$ in the Evian coast. No historical accounts of the earthquake responsible for its uplift exist, which, according to Stiros et al. (1992) could have been of magnitude greater than Ms 7.0.

\section{THE PELEKI (KERINTHOS) EMBAYMENT}

The hilltop on which the Kerinthos acropolis is built, is overlooking to its immediate south the area of Peleki (after which the Peleki bay was named), a 500 by $380 \mathrm{~m}$ embayment flanked by two elongate E-W trending limestone promontories (Fig. 2). Peleki is a Pleistocene depression filled today with Voudhoros alluvium, the formation of which was passively directed by E-W striking faults (Katsikatsos et al., 1980). 
It is highly probable that the coastal geography was different in ancient times, as it has been found to be the case in many other coastal plain environments (e.g. Kraft, 1972). Peleki is reasonably expected to have been a coastal embayment -that would provide excellent natural shelter in the otherwise inhospitable Aegean coast-, with the Kerinthos acropolis strategically positioned to watch over ancient port facilities inside it.

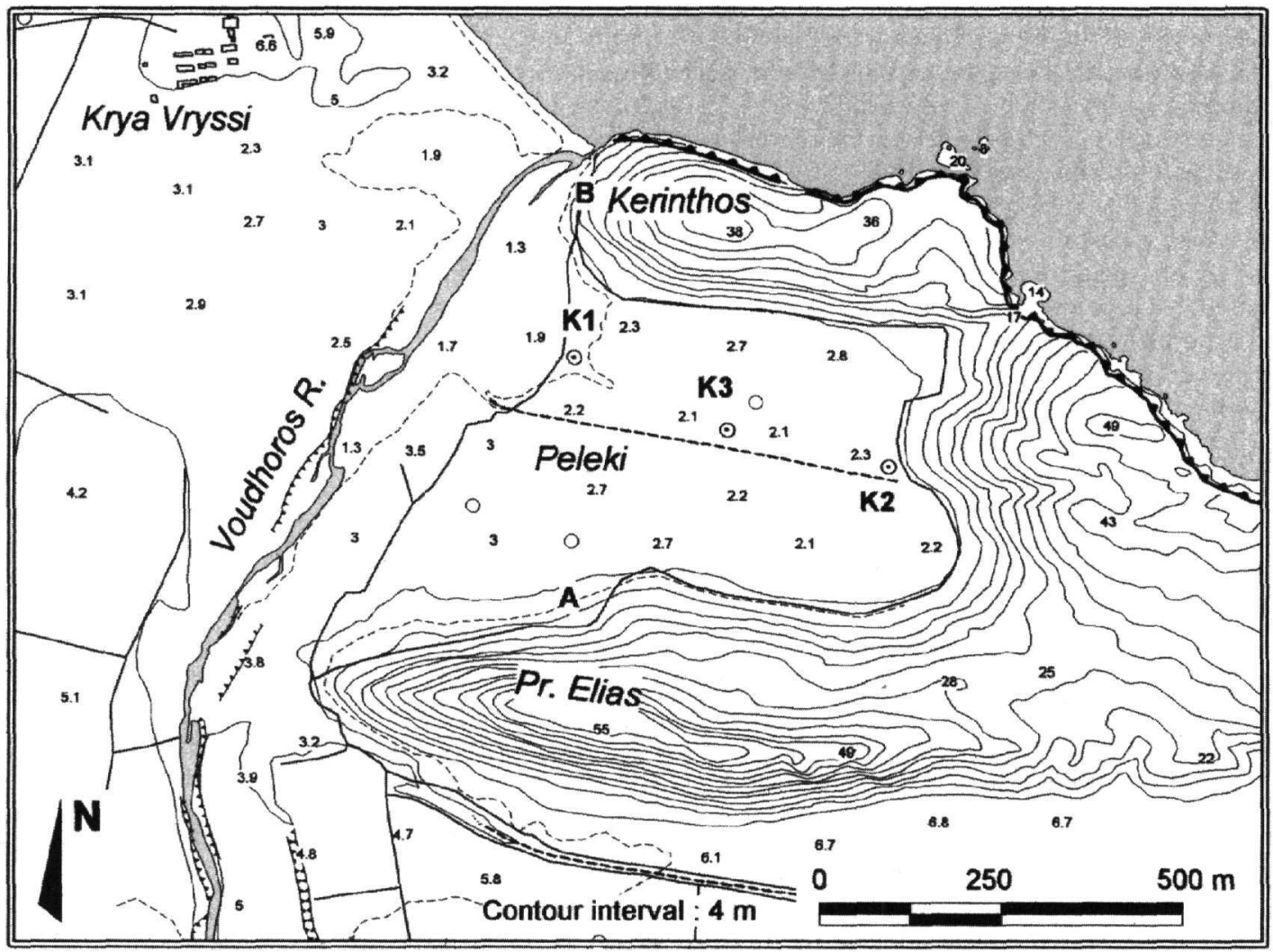

\section{Fig. 2. Detailed topography of the Kerinthos archaeological area (Peleki embayment), from 1:5.000 maps of the Hellenic Army Geographical Service.}

Although no systematic excavations have been carried out in the recent alluvium inside Peleki, abundant surface finds (Choremis, 1971), and more recent unpublished material suggest that at least its northern part was a cemetery during the Classical period $\left(5^{\text {th }}-4^{\text {th }}\right.$ cents. B.C. $)$. This implies that the infill of the embayment was already complete by that time. What is of particular interest, is the fact that no earlier findings have been reported from inside the embayment but only at more elevated areas at its periphery, where trial excavations by Sampson (1973-74, 1975a/b) yielded ruins and burials of the Middle Helladic period (1800-1500 BC) - sites A and B in Fig. 2.

\section{BOREHOLE DATA}

In view of the lack of specific historical accounts and of systematic archaeological excavations, a subsurface stratigraphic study inside Peleki was decided, in an attempt to determine the timing of its infill by Voudhoros alluvium and previous environmental conditions. In order to obtain information about the Holocene stratigraphy under the recent alluvia of Voudhoros, three $4 \mathrm{~m}$ boreholes were drilled with a portable Eijkelkamp percussion drilling set along the central axis of Peleki (Aug.-Sept. 2000, locations in Fig. 2). K1 was drilled at the mouth of the embayment, $\mathrm{K} 2$ at the head of the embayment, and $\mathrm{K} 3$ in-between the first two. Apart from field descriptions of the retrieved stratigraphic successions, selected samples from the cores were analysed for grain size, micro and macro-fossils, and other inclusions. Identification of ostracods and foraminifera was based on scan- 
ning electron microscope photographs of specimens found in various coastal areas in Greece (Tziavos, 1996, Niemi, 1990, Kambouroglou, 1989 and Tziavos, 1978) and standard reference works. Two samples of organic remains were sent to a laboratory for ${ }^{14} \mathrm{C}$ dating.

All three successions (logs in Fig. 3) ended in fine-grained brown-coloured overbank deposits of Voudhoros, plus colluvium in $\mathrm{K} 2$-which is near the base of a slope-, bearing an imprint of pedogenesis. In K1, the lowest unit consisted of well sorted, rounded gravel at its bottom with a maximum size of $5 \mathrm{~cm}$-the coarsest sediment in all three cores-, grading upwards into cyanish-grey coloured silty fine sand. Sample K1-8 from this unit contained a lot of plant remains but it was extremely poor in microfossils, with only a few fresh-water ostracods (Candona compressa, Koch). After a transitional zone of about $20 \mathrm{~cm}, 1 \mathrm{~m}$ of cyanish-grey fine-grained deposits were encountered (K1-7, 95\% silt+clay). These were rich in organic remains (rotten wood, roots), and fresh water ostracods (Candona compressa, Koch). The litho- and bio-facies of K1-7 indicates a very low energy, oxygendeficient and low salinity environment (marsh).

A large piece of wood from this unit (sample $\mathrm{K} 1-7)$ was ${ }^{14} \mathrm{C}$ dated ${ }^{4}\left({ }^{13} \mathrm{C}\right.$ corrected, error $+/-1$ s) at $1040+/-$ 90 years BP, an age that could be in conflict with the archaeological data, that unequivocally speak of Classical tombs 0,5 - $1 \mathrm{~m}$ below the surface inside the Voudhoros overbank deposits in the vicinity of K1 (Choremis, 1971) and at several other sites in Peleki. Hence, unless the archaeological data are reinterpreted differently in the future, or, until new boreholes are made close to $\mathrm{K} 1$ and more ${ }^{14} \mathrm{C}$ dates are obtained, the age of $\mathrm{K} 1-7$ should be considered problematic - even though the sample, a large piece of wood, was ideal for ${ }^{14} \mathrm{C}$-dating.

Borehole $\mathrm{K} 2$ could not penetrate beyond $1.50 \mathrm{~m}$ below m.s.l., probably because bedrock was encountered, since the site was only a few meters away from the limestone slope. The retrieved succession consisted of a 1,4 m-thick unit of cyanish-grey sandy clay+silt at the bottom, coarsening upwards into silty fine sand of the same colour. This unit was overlain by $70 \mathrm{~cm}$ of greenish-grey silty fine sand, rich in organic remains at the first $20 \mathrm{~cm}$, fining upwards into sandy silt+clay. A sample of organic remains (K2-7) was ${ }^{14} \mathrm{C}$ dated ${ }^{5}$ at $4910+/-60$ years BP $\left({ }^{13} \mathrm{C}\right.$ corrected age, error $\left.+/-1 \mathrm{~s}\right)$.

Samples K2-8 and K2-9 were taken from distinct 10-cm horizons in the lower unit, very rich in small (up to 1 $\mathrm{cm}$ ) in situ marine to brackish water bivalves and gastropods (Cerithium sp.) and benthic foraminifera (Ammonia becarii, Linne, Elphidium fichtelianum, D’Orbigny, Quinqueloculina sp.). Also, abundant fresh and brackish water ostracods were present (Candona compressa, Koch, Ilyocypris sp., Cyprinotus salinus, Bady, and fewer Loxoconcha $s p$. and Pseudopsamocythere sp.). As a whole, the lower unit of $\mathrm{K} 2$ is interpreted as a low-energy brackish to fresh water environment, with occasional increases in salinity (permitting the development of the brackish to marine macro and micro-fauna in horizons K2-8 and K2-9, which is absent in the rest of the unit). Sample K2-3 from the upper unit included low-salinity brackish water ostracod fauna (Ilyocypris sp., Candona compressa, Koch, Cyprideis torossa, Jones) and Ammonia becarii (Linne), indicating a fresh to brackish water environment.

Borehole K3 could not reach deeper than 1.90 m below m.s.1., because a very hard horizon was encountered. Since not even chips of this material could be retrieved, it is not known whether it was e.g. a beachrock. The succession above it began with $60 \mathrm{~cm}$ of oxidised greyish-yellow medium to coarse sand (fines $20 \%$ ), characterised by absence of microfossils. Overlying this unit in sharp contact were $50 \mathrm{~cm}$ of cyanish-grey medium to fine sand with increased fines (40\%), containing organic remains (plant remains, pieces of wood) and fresh to brackish water ostracods (Cyprideis torossa, Jones, Candona compressa, Koch). Calcareous oogonia (spore sacs) of the green algae Chara sp. were also abundant, indicative of clear fresh water or low salinity brackish water. In sharp contact above came $20 \mathrm{~cm}$ of greyish yellow fine and medium sand (55\%) and $45 \%$ silt+clay (K3-7), containing plant remains and similar ostracod fauna (Cyprideis torossa, Jones and Candona compressa, Koch) and Chara sp. Overlying K3-7 were $50 \mathrm{~cm}$ of greyish-yellow (oxidised) fine and medium sand (25\% fines), containing no microfossils, like the unit of K3-10. Finally, $60 \mathrm{~cm}$ of greenish-grey coloured fine sands and silts were encountered - sample K3-4 from this unit also contained no microfossils.

\section{DISCUSSION - CONCLUSIONS}

The stratigraphy of the boreholes inside Peleki, is characterised by significant lateral facies changes underneath the overbank deposits of Voudhoros. In an overall sense, the dark-coloured silts/clays and fine sands rich in organic matter and containing predominantly brackish water microfossils were deposited in a shallow, protected, marshy coastal environment. This environment was established at least since 5000 years $\mathrm{BP}$, as the ${ }^{14} \mathrm{C}$ age of K2-7 indicates.

\footnotetext{
${ }^{4}$ Lab. No. GX-27132 (Geochron Laboratories).

${ }^{5}$ Lab. No. GX-27281 (Geochron Laboratories).
} 
${ }^{14} \mathrm{C}$ yrs B.P.

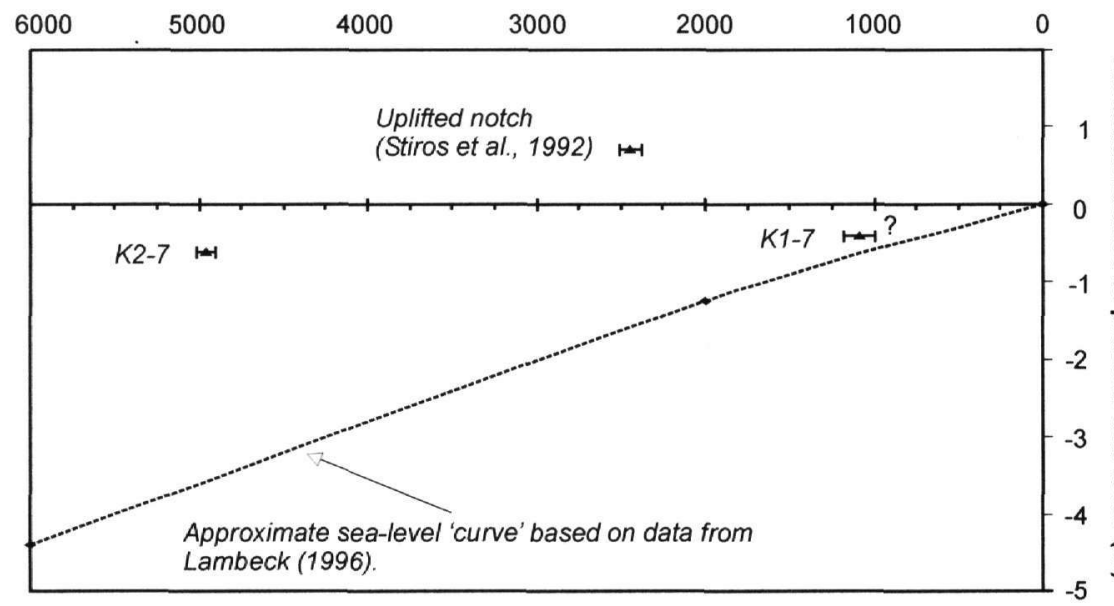

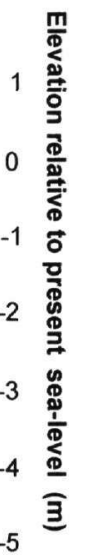

Fig. 4. Approximate sea-level 'curve' (data from Lambeck, 1996), and elevations of ${ }^{14} \mathrm{C}$ dated horizons. The uplifted notch dated by Stiros et al. (1992) is also plotted. Error bars indicate the accuracy of ${ }^{14} \mathrm{C}$ dates.

Given the inherent complexity of such transitional sedimentary environments (Reineck \& Singh, 1973), until more cores are sampled to allow the establishment of a more complete 'stratigraphic section' along -and across- the Peleki embayment, any interpretation of the details of the presented data can only be considered preliminary. The main question of interest here is the origin of the coarser sediments that were encountered in the boreholes. These contained no traces of marine fauna (reasonably to be expected should they were of marine origin), something that could be indicating they are deposits of Voudhoros -e.g. flood surges inside the shallow-water Peleki embayment.

An interesting outcome of the subsurface study was the evidence for significant tectonic uplift of the coast, a factor acting in favour of the Voudhoros plain progradation and infill of the Peleki embayment. The present elevation of the contact between the Voudhoros overbank deposits and the underlying brackish water sediments, is systematically above present sea-level by at least $30 \mathrm{~cm}$ - a conservative figure measured above the possible error margin in the determination of the borehole elevations, which was based on spot heights of very accurate HAGS 1:5.000 maps. More specific information, concerning the total amount of coastal uplift in the last 5 millenia can be extracted from the ${ }^{14} \mathrm{C}$ age of $\mathrm{K} 2-7$, by comparing the present elevation of the sample to a Holocene sea-level curve (Fig. 4). Data from Lambeck (1996) were used to plot the approximate 'curve' of Fig. 4, which is accurate enough for our purposes and shows that when K2-7 was deposited, sea-level was about 3,6 m lower than present. The present elevation of K2-7 (-0.6 m) implies uplift of the coast by $3 \mathrm{~m}$ above the sea-level at the time of deposition. This is a minimum figure -because the depth of water during the time of deposition of K2-7 and the subsequent sediment compaction that has taken place since is not known-, and translates to a (minimum) mean uplift rate of $0.60 \mathrm{~mm} / \mathrm{yr}$ for the past $4960 \mathrm{yrs}(0.67 \mathrm{~mm} / \mathrm{yr}$ if $30 \mathrm{~cm}$ of water depth is assumed for K2-7). The notch dated by Stiros et al. (1992) at Kymasi, is about $2.2 \mathrm{~m}$ higher than sea-level at the time of its formation (Fig. 4), yielding a mean uplift rate of about $0.9 \mathrm{~mm} / \mathrm{yr}$ for the past $2445 \mathrm{yrs}$. This rate is significantly high, and comparable to long-term uplift rates in the southern margin of the Corinth Gulf ( $1.1 \mathrm{~mm} / \mathrm{yr}$ being a conservative figure for the Helike fault - McNeill et al., 2000). Even if the above two figures are crude first estimates based on a low-accuracy sea-level curve, their difference could still reflect changes in the rate of coastal uplift during the Holocene.

Another point of interest is the possibility of identifying palaeoseismic events from the stratigraphic record, since the sequences preserved in coastal wetlands can potentially 'document' earthquake-induced changes (e.g. Cundy et al., 2000), especially if coseismic uplift is large, as Stiros et al. (1992) propose. In the Peleki sequences, unambiguous indications of emergence episodes could not be identified - e.g. subaerial deposits intercalated in the brackish sediments; however, more detailed analyses could yield fruitful results in the future.

With the preliminary data at hand, it is inferred that coastal uplift may have been accommodated in several episodes uplifting by a few tens of $\mathrm{cm}$ each time, rather than a few events of metre-scale coseismic uplift as suggested by Stiros et al. (1992), that would probably uplift the deposits above sea-level - at least as far as the Peleki area is concerned. Another possibility would be that coseismic uplift is superimposed on significant slow nonseismic movements, as proposed e.g. by Stewart (1996) for the Helike fault (Corinth gulf). 

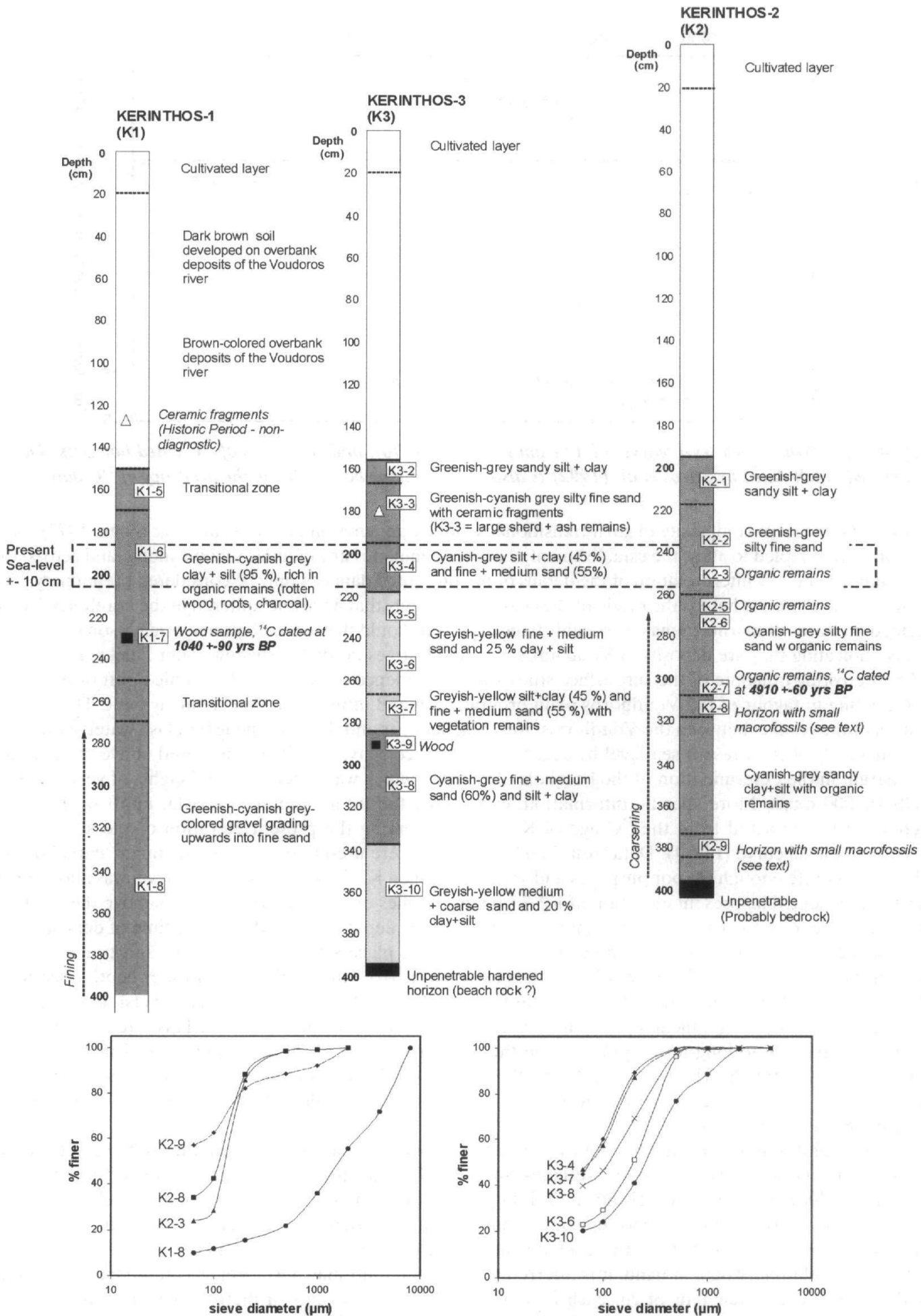

Sieve diameters used : 64, 100, 200, 500, 1000, 2000 and $4000 \mu \mathrm{m}$

Fig. 3. Borehole logs and cumulative grain-size distribution curves for selected samples. 


\section{REFERENCES}

CHOREMIS, A., 1971. Kerinthos, Archaeologikon Deltion, 26, Chronika B1, 261 (in Greek).

CUNDY, A., KORTEKAAS, S., DEWEZ, T., STEWART, I., COLLINS, P., CROUDACE, I., MAROUKIAN, H., PAPANASTASSIOU, D., GAKI-PAPANASTASSIOU, K., PAVLOPOULOS, K. AND A. DAWSON, 2000. Coastal wetlands as recorders of earthquake subsidence in the Aegean: a case study of the 1894 Atalanti earthquakes, Marine Geology, 170, 1-2, 3-26.

FYTROLAKIS, N., ALEXOULI-LIVADITI, A., LIVADITIS, G. AND J. KYROUSSIS, 1988. Geomorphological study and observations on the hydrogeology and pollution of surface and subterranean waters in the Kireas and Nileas basins (N. Evia). Bull. Geol. Soc. Greece, XX/3, 115-132 (in Greek).

HOPE-SIMPSON, R. AND O. DICKINSON, 1979. A Gazeteer of Aegean Civilization in the Bronze Age, Vol. VII, Göteborg.

KAMBOUROGLOU, E., 1989. Eretria - palaeogeographic and geomorphological evolution during the Holocene, PhD Thesis, Univ. of Athens, 237 pp. (in Greek).

KATSIKATSOS, G., KOUKIS, G. AND M. FYTIKAS, 1981. Geological map of Greece (1:50.000) - PsachnaPelion sheet, IGME, Athens.

KATSIKATSOS, G., KOUNIS, G., FYTIKAS, M., METTOS, A. AND M. VIDAKIS, 1980. Geological map of Greece (1:50.000) - Limni sheet, IGME, Athens.

KRAFT, J., 1972. A reconnaissance of the geology of the sandy coastal areas of eastern Greece and the Peloponnese, Univ. of Delaware, Tech. rep. 9, 158 pp.

LAMBECK, K., 1996. Sea-level change and shoreline evolution in Aegean Greece since upper Palaeolithic time, Antiquity, 70(169), 588-611.

LEONTARIS, S. AND TH. GOURNELLOS, 1991. Observations on the evolution of the drainage network of Evia island in relation to its geological structure, Bull. Geol. Soc. Greece, XXV/4, 25-38 (in Greek).

MCNEILL, L., COLLIER, R. AND F. D' AJELLO CARRACIOLO, 2000. Tectonic and geomorphic evolution of the southern gulf of Corinth rift margin: focus on the Eastern Eliki fault footwall block, $3^{\text {rd }}$ Int. Congr. on ancient Helike and Aigialeia, Nikolaiika 6-9 Oct. 2000, Abstr., p. 15-16.

NIEMI, T., 1990. Palaeoenvironmental history of submerged ruins on the northern Euboean gulf coastal plain, Central, Greece, Geoarchaeology, 5, 4, 323-347.

REINECK, H. AND I. SINGH, 1973. Depositional sedimentary environments, Springer Verlag, $439 \mathrm{pp}$.

ROBERTS, S. AND J. JACKSON, 1991, Active normal faulting in central Greece: an overview, in Roberts, A.M., Yielding, G. and S. Freeman (eds), "The geometry of normal faults", Geological Society of London Sp. Publ. 56, 125-142.

SACKETT, L., HANKEY, V., HOWELL, R., JACOBSEN, T. AND M. POPHAM, 1966. Prehistoric Euboea, contributions toward a survey, Annual of the British School at Athens, 71, 33-113.

SAMPSON, A., 1973-1974. Archaeologikon Deltion, 29, Chronika, 484-487 (in Greek).

SAMPSON, A., 1975a. A middle Helladic settlement at Peleki, Archaeologika Analekta ex Athinon (AAA), VIII, 28-31 (in Greek).

SAMPSON, A., 1975b, Excavation at the Kerinthos acropolis, Archaeologika Analekta ex Athinon (AAA), VIII, 32-37 (in Greek).

SAPOUNA-SAKELLARAKI, E., 1996. Mycenaean Kerinthos, in "Minotaur and Centaur. Studies in the Archaeology of Crete and Euboea" (D. Evely, I.S. Lemos, and S. Sherratt, eds.), BAR International Series, 638, 106-110.

STEWART, I., 1996. Holocene uplift and paleoseismicity on the Eliki Fault, Western Gulf of Corinth, Greece, Annali di Geofisica, XXXIX, 3, 575-588.

STIROS, S., ARNOLD, M., PIRAZZOLI, P., LABOREL, J., LABOREL, F. AND S. PAPAGEORGIOU, 1992. Historical coseismic uplift on Euboea island, Greece, Earth. Planet. Sci. Letters, 108, 109-117.

TZIAVOS, CH., 1978. Distribution of recent foraminifera and ostracoda from the Sperchios river delta and Maliakos gulf, Thalassografica, 2, 1, 57-81.

TZIAVOS, CH., 1996. Oceanographic study and palaeo-environmental evolution of the Amvrakikos gulf, $\mathrm{PhD}$ Thesis, Univ. of Athens, 319 pp. (in Greek). 